\author{
EFRAIM SiCHER \\ (D) https://orcid.org/0000-0001-5067-8379 \\ Ben-Gurion University of the Negev
}

\title{
A Poetics of the Holocaust? Three Exemplary Poets ${ }^{*}$
}

\begin{abstract}
Aвstract: Whether or not we understand the Holocaust to be unique or following a series of catastrophes in Jewish history, there is no doubt that the writing that came out of those traumatic events is worth examining both as testimony and as literature. This article looks again at Holocaust poetry, this time circumventing Adorno's much-cited and often misquoted dictum on poetry after Auschwitz. The essay challenges the binary of either "Holocaust poetry is barbaric and impossible" or "art is uplifting and unaffected by the Holocaust." I analyse three individual cases of Holocaust poetry as a means of both survival and testimony during the Holocaust - not retrospectively or seen by poets who were not there. Aesthetic and ethical issues are very much part of a writing in extremis which is conscious of the challenge well before Adorno and critical theory. In a comparison of Celan, Sutzkever, and Miłosz we can see their desperate attempt to write a poetry that meets the challenge of the historical moment, for all the differences between them in their cultural backgrounds, language traditions, and literary influences. As I argue, although scholars and critics have read these poets separately, they should be studied as part of the phenomenon of grappling with an unprecedented horror which they could not possibly at the time understand in all its historical dimension and outcome. We should no longer ignore their sources and antecedents in trying to gauge what they did with them in forging a "Holocaust poetics" that would convey something of the inadequacy of language and the failure of the imagination in representing the unspeakable, which they personally experienced on a day to day basis. By not reading "after Adorno" we can arrive at a more nuanced discussion of whether there is a Holocaust poetics.
\end{abstract}

KeYwords: Holocaust, poetry, trauma, poetics, Abraham Sutzkever, Paul Celan, Czesław Miłosz

* I am grateful to Vivian Liska for her insights into Celan in her Axel Springer lecture, Hebrew University of Jerusalem, 24 December 2014, as well as to David Roskies, Daniel Feldman, and Hannah Pollin-Galay for their helpful comments. 


\section{Introduction}

Scholars often talk about poetry "after Auschwitz." That, properly speaking, is a question of the politics of memory. This essay looks at poetry written during, not after, the Holocaust in order to consider whether one can speak of a "Holocaust poetics." I ask what might be the implications of such an approach for our reading of Celan, Miłosz, Sutzkever, and others who wrote in the uncertainty and instability of a war that was not over, before the full horror was known and the Holocaust entered public consciousness. Although there is no space for them in this brief discussion, I would also mention poets who were conscripted to the forced labour battalions, such as Miklós Radnóti, whose poems were found when his body was exhumed from a mass grave, and ghetto poets who perished, such as Władysław Szlengel and Yitskhak Katsenelson. ${ }^{1}$ Their poems are literally messages in a bottle, ${ }^{2}$ and their writing may be considered early testimony. Unlike post-Holocaust poetry, poetry composed during the Holocaust by those who were there and as it was happening is a writing in extremis that is not just a cry of grief but challenges us to accept that artistry and experience are not contradictory. On the contrary, the force of truth comes across in artistic form in ways that are shocking, disturbing, and affective. And yet, as I will show, these poets did not emerge out of a vacuum; they worked in established traditions of Romantic and modernist poetry, but nevertheless were conscious of the strain on poetic language of unprecedented and unspeakable horror.

Much has been written about Holocaust testimony, or about Holocaust novels. There has been less discussion of the aesthetic, ethical, and hermeneutic issues that Holocaust poetry has in common with Holocaust testimony. Ezrahi quotes a Yiddish ghetto poet, Mendel Mann, "This was in most cases a desperate poetry, but passionate and sacred. [...] I admired not so much their literary form, but their faith, their confidence in the Jewish word." ${ }^{3}$ David G. Roskies includes ten ghetto poets in his important anthology of Jewish literature through the centuries Literature of Destruction, and Edward Alexander considers both writers who were there and those who wrote elsewhere in the aftermath in Yiddish and Hebrew. ${ }^{4}$ Several anthologies of contemporary poems evoke the witnessing

${ }^{1}$ See the poems included in F.W. Aaron: Bearing the Unbearable: Yiddish and Polish Poetry in the Ghettos and Concentration Camps. Albany 1990; D.G. Roskies (ed.): Voices from the Ghetto. New Haven 2019.

2 S. VICE: "Holocaust Poetry and Testimony." Critical Survey 2008, vol. 20, no. 2, pp. 7-8.

${ }^{3}$ Quoted in S.D. Ezrahi: By Words Alone: The Holocaust in Literature. Chicago 1980, p. 21.

${ }^{4}$ D.G. Roskies (ed.): The Literature of Destruction: Jewish Responses to Catastrophe. Philadelphia 1989; E. Alexander: "Patterns of Holocaust Poetry: Representative Voices in Yiddish and Hebrew.” In: A.D. Colin (ed.): Argumentum e Silentio: International Paul Celan Symposium. Berlin 1987, pp. 296-319. 
of war poetry and political protest in general or "bear witness" vicariously to the Holocaust. ${ }^{5}$ Yet the existence of a Holocaust poetics has not been discussed beyond some general comments regarding individual poets and certainly not in a comparative context, although the issue has been broached by Roskies in relation to Yiddish poets Sutzkever and Katsenelson. ${ }^{6}$

Susan Gubar has pointed to the paradox of Holocaust poetry caught in a vice between the inadequacy of minimalism and verbosity that blocks testimony. ${ }^{7}$ She proposes that poetry can nevertheless be testimonial in ways that show the inadequacy of language to testify: "Verse is the most unrealistic of languages, [...] and thus it produces a posthumous facsimile of a living voice." ${ }^{\prime}$ Gubar's promotion of "Holocaust poetry," or more precisely post-Holocaust poetry in English which excludes wartime writing, derives from her anxiety that memory of the genocide is "dying" with the last survivors and rests on her conviction that the imagery of poetry can prevent foreclosure of memory of an event which in many ways resisted narration, as well as prevent it slipping into cultural amnesia. ${ }^{9}$ Antony Rowland and Robert Eaglestone in their edited special issue of Critical Survey entitled "Holocaust Poetry" and Rowland in his book of that title look at poetry written mainly in English after 1945 as exemplary of poetry "after Auschwitz" that is characterised by an "awkward poetics." Such all-inclusiveness in the claim for a post-Holocaust poetry obfuscates the fact that much of the poetry by survivors (including Celan and Sutzkever) does not deal with the Holocaust, although it could be argued that everything they wrote after the Holocaust is informed by their personal and collective experience, which must necessarily shape their conception of poetry and of history. ${ }^{10}$

In any case, these are wide claims for the truth value of poetry as such and do not get at the fundamental issues in the concept of poetry as testimony, which has generally been assumed to be a characteristically prose genre, as if only prose

${ }^{5}$ For example, C. Forché (ed.): Against Forgetting: Twentieth-Century Poetry of Witness. New York 1993; and its companion volume C. ForCHÉ, D. Wu (eds.): The Poetry of Witness: The English Tradition, 1500-2001. New York 2014; among several anthologies of "Holocaust poetry" are H. Schiff (ed.): Holocaust Poetry. London 1995; M.M. Striar (ed.): Beyond Lament: Poets of the World Bearing Witness to the Holocaust. Evanston 1998; M. Teichman, S. Leder (eds.): Truth and Lamentation: Stories and Poems on the Holocaust. Urbana 1994.

${ }^{6}$ D.G. Roskies: “Did the Shoah Engender a New Poetics?" In: K. Smola (ed.): Eastern European Jewish Literature of the 20th and 21st Centuries: Identity and Poetics. Munich-Berlin 2013, pp. 347-363.

7 S. Gubar: "The Long and Short of Holocaust Verse." New Literary History 2004, vol. 35, no. 3, pp. 443-445.

8 Ibidem, p. 450.

9 S. Gubar: Poetry after Auschwitz: Remembering What One Never Knew. Bloomington 2003, pp. 7-8, 146.

${ }^{10}$ See A. Rowland: Holocaust Poetry. Edinburgh 2005; A. Rowland, R. Eaglestone (eds.): "Holocaust Poetry special issue." Critical Survey 2008, vol. 20, no. 2. 
could be representational and only the representational could testify. Exceptionally, Shoshanna Felman and Dori Laub have laid claims for poetry and literature in general to be read as testimony. ${ }^{11}$ Rowland has remarked on the lack of critical attention to testimonial poetry and he has suggested that only with mass conscription in the First World War did poets find themselves on the front line in a position of witnessing extreme events that went beyond what had previously been imagined. Rowland understands testimony here in a judicial sense, requiring the reader to bear witness in what Rowland calls "hyper-attentiveness," but such testimonial poetry may be able to express the feelings of the survivor and the ephemeral or sublime aspects of trauma in ways that are beyond the capabilities of prose. ${ }^{12}$ The assumption here of an ethical contract with the reader makes testimonial poetry more than merely performative or an act of political protest. Poetry can achieve epiphany, and as Robert Antelme remarked on poems by Maurice Honel about survival in a Nazi prison camp, it can affect the reader more than the false objectivity of prose or photographs and it resists the denial or burying of testimony that Antelme observed immediately after the liberation:

Poetry did not, surely, run so great a risk of creating that naked, "objective" testimony, that kind of abstract accusation, that photograph that only frightens us without explicitly teaching anything. It could, on the contrary risk fleeing the reality of the camps, letting that reality be glimpsed only through a melodic counterpoint, through themes of nostalgia that surround but never penetrate this reality of fog and words-the sun, laughter, color, and so on. ${ }^{13}$

Poets who were conscripts in regular army units were forced witnesses of total destruction; concentration camp inmates, on the other hand, were forced to witness their own imminent annihilation, so that each word they breathed and wrote was an act of survival. Referring to Celan's "The Meridian," Alvin Rosenfeld has termed the representation of death in the work of such Holocaust poets as Paul Celan and Nelly Sachs a "poetics of expiration"14 not in the sense of an inversion of Romantic inspiration but in the language of life that has become death, the bare breath of words. One could say that Holocaust writing speaks in a language of negativity to convey the impossibility of speaking. In doing so, it can testify.

${ }^{11}$ S. Felman, D. Laub: Testimony: Crises of Witnessing in Literature, Psychoanalysis, and History. New York 1992.

12 A. Rowland: Poetry as Testimony: Witness and Memory in Twentieth-Century Poems. New York-London 2014, pp. 1-7.

${ }^{13}$ R. Antelme: "Poetry and the Testimony of the Camps." In: D. Dobbels (ed.): On Robert Antelme's The Human Race: Essays and Commentary. Evanston 2003, p. 33.

${ }_{14}$ A.H. Rosenfeld: A Double Dying: Reflections on Holocaust Literature. Bloomington 1980, p. 85 . 
Poetry, no less than fiction, speaks to us as testimony, but the poetic form has a special talent for collective memory. In the Bible, poetry serves as a testimony which Moses bequeaths to the people of Israel in chapter 32 of the Book of Deuteronomy (shirat haazinu). The Holocaust has similarly left a legacy of responsibility for testimony to witness beyond the six million dead, beyond the generation of survivors. As Elie Wiesel commented, his generation invented a new literary genre, testimony. ${ }^{15}$ Testimony grants agency to the witness, even though in reality the witness was often totally powerless. The witness, Shoshana Felman writes, has become a key figure that personifies the ethical drive of the literary text. The writing of testimony, Felman insists, is a discursive practice; as opposed to pure theory: “To testify-to vow to tell, to promise and produce one's own speech as material evidence for truth-is to accomplish a speech act [...]. As a performative speech act, testimony in effect addresses what in history is action that exceeds any substantialized significance [...]." ${ }^{16}$ To put it a little differently, testimony is a literary form that carries with it, in its moral obligation to tell the truth, a narrative voice that speaks the unspeakable, that tells what is impossible to tell, beyond the bounds of a conventional conceptualisation of historical reality. This approach enables Felman to read Camus and Dostoevsky, as well as the poetry of Celan and the taped witnessing of survivors, as testimony, thus removing the generic barrier between fiction and truth and drawing attention to the crisis of hermeneutics and epistemology. This is also a crisis in the reader's experience as they are themselves made witnesses to the witness who exceptionally survived, who were witnesses of life as death. Readers are made privy to a terrible knowledge that would be inconceivable if it was not being narrated. Language in all these texts claims the truth of an unthinkable reality of death as the writer-witness creates a new anti-aesthetics which makes room for an "I-you" that was eliminated by the law of genocide. ${ }^{17}$

\section{Poetry after Adorno}

We might think that Holocaust poetry is sui generis, having come into being as a result of the caesura of the most traumatic and unthinkable event in human history. The question "Is there a Holocaust poetics?" might have no definitive answer, but it is a question we should ask if we want to know to what extent

${ }^{15}$ E. Wiesel: "The Holocaust as Literary Inspiration.” In: E. Wiesel, L. DAwidowicz, D. Rabinowitz, R.M. Brown (eds.): Dimensions of the Holocaust. 2nd ed. Evanston 1990, p. 9.

${ }^{16}$ S. Felman: "Education and Crisis, or the Vicissitudes of Teaching." In: S. Felman, D. Laub: Testimony..., p. 5; emphasis in the original.

${ }^{17}$ Ibidem, pp. 25-40. 
poets who wrote during and about the Holocaust were able to find a new poetic language for what they experienced and to what extent they adapted existing conventions and paradigms to an ironic mode. Yet discussion of Holocaust poetry and Holocaust literature in general has for too long been overshadowed by writing after Adorno. Before offering a reading of Holocaust poetry that was written and read before critical theory quoted or misquoted Adorno and made him the measure of judgement, I wish to set the record straight.

In much of the discussion on literature "after Auschwitz," the starting point is Theodor Adorno's statement, made in his essay "Kulturkritik und Gessellschaft" (1949), that to write poetry after Auschwitz is barbaric: "Nach Auschwitz ein Gedicht zu schreiben ist barbarisch" ("To write a poem after Auschwitz is barbaric"). ${ }^{18}$ Yet it is often forgotten that this was said in the immediate post-war period, when some German intellectuals wished to make a new start and put the Hitler period behind them, while others saw that the destruction of humane values represented by "Auschwitz" had irrevocably damaged the possibility of writing as before. ${ }^{19}$ Adorno was defending cultural criticism from the reification of a totalising society in which it faced the final stage of the dialectic of culture and barbarism. Therefore, we should think of the phrase "after Auschwitz" not only in historical terms but also in the philosophical framework of the Frankfurt School's investment of hope in culture to help bring about a better world. For Adorno, Auschwitz was an epistemological as well as ontological break, an "earthquake" that shook the foundations of Western philosophy. ${ }^{20}$ Every philosophical term, everything we think about the human condition had to be re-examined in order to understand the conditions of the cultural critic. ${ }^{21}$

Adorno's dichotomy of "culture" and "barbarism" is one which George Steiner questioned in his collection of essays Language and Silence (1967) when he remarked that the SS officer may very well have gone home to his wife and family after gassing Jews and spent the evening reading Rilke. This showed, to Steiner's mind, how culture and barbarity lay cheek by jowl; it questioned whether the humanities did in fact humanise. Weimar and Buchenwald were adjacent. Freedom meant nothing more than a mocking sign over the gates of Auschwitz-Birkenau. The belief that the humanities necessarily humanise was

18 T.W. Adorno: "Kulturkritik und Gesellschaft." In: T.W. Adorno: Gesammelte Schriften. Vol. 10. Frankfurt/M. 1951, p. 30; T.W. Adorno: "Cultural Criticism and Society." In: T.W. Adorno: Prisms. Trans. S.M. Weber, S. Weber. Cambridge 1981, p. 34.

${ }^{19}$ For the postwar debate see J.M. Hoyen: "Flowerless Gardeners: Poetry after Auschwitz." In: D. Stuber (ed.): Holocaust Literature. Ipswich 2016, pp. 182-199.

20 T.W. Adorno: Negative Dialectics. Trans. E.B. Ashton. New York 1973, p. 361.

${ }^{21}$ For an analysis and critique of Adorno's statements and examples of their misuse or misquotation see M. Rothberg: "After Adorno: Culture in the Wake of Catastrophe." New German Critique 1997, no. 72, pp. 45-81; M. Tetтlebaum: “Nothing is meant quite literally”: Adorno and the Barbarism of Potry of the Ausztwitz." In: Holocaust Literature..., pp. 200-213. 
placed in doubt by the bestiality of the 20th century. Literature and sadism can apparently coexist:

Literary values and the utmost of hideous inhumanity could coexist in the same community, in the same individual sensibility; and let us not take the easy way out and say "the man who did these things in a concentration camp just said he was reading Rilke. He was not reading him well." That is an evasion. He may have been reading him very well indeed. ${ }^{22}$

Nonetheless, Steiner believes the critic's role after Auschwitz, in the age of bestiality, is to preserve the values of humane liberalism by showing what to read and how to read it. The possibility of humaneness, Steiner believed, lies in the cathartic power of literature. We cannot know whether the SS officer was reading Rilke "properly" because the Nazis put literature and language to their own purposes to suit their ideological and racist vision. Or it may be true that Western culture was itself contaminated by barbarity, if not complicit through silence or active participation. Western civilisation, with its clearly delineated generic and ontological boundaries and its linguistic and philosophical assumptions of a common humanity, was an illusion dispelled by the Nazis' race laws. Yet it may have been an illusion before the mass book-burnings on 10 May 1933. Writing in 1940, after the Molotov-Ribbentrop pact sealed the fate of Poland, Walter Benjamin warned historical materialists that the treasures of culture could not be contemplated without horror considering their origin: "Es ist niemals ein Dokument der Kultur, ohne zugleich ein solches der Barbarei $\mathrm{zu}$ sein" ("There is no document of civilisation which is not at the same time a document of barbarism"). ${ }^{23}$

Adorno's famous declaration (often quoted incomplete and out of context) did not, however, cancel the possibility of writing "after Auschwitz" so much as question its status and mode in conditions of total reification. In remarks directed at Jean-Paul Sartre's avowal of literary "engagement," Adorno conceded in 1961, "Den Satz, nach Auschwitz noch Lyrik zu schreiben, sei barbarisch, möchte ich nicht mildern; negativ ist darin der Impuls ausgesprochen, der die engagierte Dichtung beseelt" ("I do not want to soften my statement that it is barbaric to continue to write poetry after Auschwitz; it expresses, negatively, the impulse that animates committed literature"). ${ }^{24}$ If the aim of art was to give aesthetic

${ }^{22}$ G. Steiner: Language and Silence: Essays on Language, Literature, and the Inhuman. New York 1967, p. 61.

${ }^{23}$ W. Benjamin: “Über den Begriff der Geschichte.” In: W. Benjamin: Illuminationen: ausgewählte Schriften. Frankfurt/M. 1977, p. 254; W. Benjamin: "Theses on the Philosophy of History." In: W. Benjamin: Illuminations. Ed. H. Arendt. Trans. H. Zohn. New York 1968, p. 258.

${ }^{24}$ T.W. Adorno: "Engagement." In: T.W. Adorno: Gesammelte Schriften. Vol. 11. Frankfurt/M. 1951, p. 422; T.W. Adorno: Notes to Literature. Vol. 2. Trans. S.W. Nicholsen. New York 1992, p. 87. 
pleasure, what pleasure could be squeezed out of the screams of the victims? To derive aesthetic pleasure from depiction of the victims seemed to Adorno to trivialise and distort their experience. Yet suffering, too, had its right to expression, Adorno wrote in Negative Dialectics (1966): "hence it may have been wrong to say that after Auschwitz you could no longer write poems," but it was not wrong to question living "after" when the very possibility of life was daunted by the survivor's guilt at having been spared and by the absolute negativity in the "destruction of nonidentity," now "ideologically lurking." ${ }^{25}$ Not only was poetry possible, it was necessary, as Sartre remarked immediately after the war in What Is Literature?, in a world that can do without literature and even better without humanity. ${ }^{26}$ This leaves unresolved the paradox of Adorno's conviction that any attempt to reject culture or to subscribe to the "garbage" of post-Auschwitz culture amounted to the same barbarism. Rather, as Jean-François Lyotard has proposed in his critique of Negative Dialectics, an "anesthesia" is needed to resist the "amnesia" in the concealment that comes with utterance in all art, especially in a technological age of production. ${ }^{27}$

Postmodernism refers to the rupture in history we call the Holocaust as a symptom of the normative impossibility of speech and the indeterminacy of referentiality. ${ }^{28}$ Asking whether the gas chambers can be separated from the "negativity of language," Susan Shapiro urges: "Not only can we, but we must make this separation." ${ }^{29}$ Shapiro argues that the poems of Celan and Sachs are extreme cases of discourses whose failure is an integral part of their testimony, but this does not indicate the inadequacy of poetry to express the unspeakable so much as the poet's need to find a language that demonstrates its failure to represent the Holocaust. ${ }^{30}$ Any poetic form has to be commensurate with the events or experience which it is representing. An event such as the Holocaust which is unthinkable requires a form that represents the unthinkable.

${ }^{25}$ T.W. Adorno: Negative Dialectics..., pp. 362-363.

${ }^{26}$ J.-P. SARTRE: What Is Literature? New York 1949, p. 297.

${ }^{27}$ J.-F. Lyotard: Heidegger and "the Jews". Trans. A. Michel, M.S. Roberts. Minneapolis 1990, pp. 43-48.

${ }^{28}$ S.E. ShaPIRo: "Failing Speech: Post-Holocaust Writing and the Discourse of Postmodernism.” Semeia 1987, vol. 40, pp. 65-91.

${ }^{29}$ Ibidem, p. 86.

${ }^{30}$ Ibidem, p. 87. 


\section{Celan's Poetry of Negativity}

If Adorno said that it would be barbaric to write a poem ("ein Gedicht") or poetry ("Dichtung") after Auschwitz, we may ask whether the lyricism which Adorno apparently felt to be a betrayal of the victims was in fact the very opposite: a subversion of poetic language by invoking familiar conventions in a cruel irony that mocks and undermines our basic definitions of life and death. ${ }^{31}$ If Paul Celan's "Todesfuge" sounded to Adorno incongruously and even obscenely lyrical, it speaks nevertheless, perhaps even more so, because the lyricism disturbs.

Schwarze Milch der Frühe wir trinken sie abends wir trinken sie mittags und morgens wir trinken sie nachts wir trinken und trinken. ${ }^{32}$

Black milk of daybreak we drink it at evening we drink it at midday and morning we drink it at night we drink and we drink. ${ }^{33}$

This familiar first line of Paul Celan's “Todesfuge" erases any remaining Romantic idea of the harmony of man and nature. The "black milk of morning" refuses to be read figuratively, but as a literal representation of the morning coffee, or what passes for coffee, which the prisoners routinely drink before being forced out to work at the crack of dawn. ${ }^{34}$ Yet it is also aligned asyntactically in the poem with death. The ballad-like repetition ("wir trinken sie mittags und morgens wir trinken sie nachts / wir trinken und trinken"), that sounds more appropriate for a German beer-hall song, mocks any lyricism when the repetition literally represents the unremitting brutality, the dehumanisation, and the starvation diet. ${ }^{35}$

The "black milk" does not nurture anything but death; it is a literal imbibing of death but also a denaturing image. ${ }^{36}$ Yet a psychoanalytic reading of a thirsting child does not take account of that literalisation which resists a metaphorical reading. The black humour of a grave in the air similarly denies any figurality

${ }^{31}$ In that regard Celan's disturbing lyricism may not be so far from Adorno's position; see J. ZILcosky: "Poetry after Auschwitz? Celan and Adorno Revisited." Deutsche Vierteljahrsschrift für Literaturwissenschaft und Geistesgeschichte 2005, vol. 79, no. 4, pp. 670-691.

32 P. Celan: Die Gedichte. Ed. B. Wiedemann. Berlin 2018, p. 46; all further references will be to this edition.

${ }^{33}$ P. Celan: Selected Poems and Prose. Trans. J. Felstiner. Bilingual edition. New York 2001, p. 31.

${ }^{34}$ J. Felstiner: Paul Celan: Poet, Survivor, Jew. New Haven 1995, p. 33.

${ }^{35}$ Ibidem, p. 35

${ }^{36}$ S. Felman: "Education and Crisis...," p. 40. 
if we recall that the smoke in the sky from the crematoria was quite literal and did release victims from the living death cramped in the barracks. The forced grave-digging for the victims of Nazi genocide mockingly releases them to a celestial freedom in a parody of Nazi cynicism: "wir schaufeln ein Grab in den Lüften da liegt man nicht eng" ("We shovel a grave in the air / where you won't lie too cramped"). ${ }^{37}$ More to the point is the cynicism of an orchestra which plays while prisoners are marched out to the daily labour that is slowly killing them or plays while graves are dug and prisoners are being massacred. The sadistic perversion of the order of things here has been normalised as a literal and unpoetic reality. The "we" of the narrator's point of view, moreover, as objects of annihilation, are claiming subjectivity when they have been assigned to death, to non-existence, to silence. Indeed, the poet speaks as part of the Jewish collective and has a familiar "du" relation with the black milk, thus embodying in his voice the disembodiment of the Jews who have no right to human existence or speech and can only "dance" to order. The dehumanised "we" is juxtaposed with a "man" who lives in a house, for whom these are "seine Juden" - a relation of master and slave seen ironically from the abject position of the victims forced to dig graves for Jews cremated in the ovens or massacred in mass shootings. The irony is deepened by the very writing of the poem, by the poet's "death-fugue" of the poem's title (which is, significantly, not given a definite or indefinite article).

The SS officer is identified as the Master from Germany - the master of death, who writes to his lover Margarete, a Faustian figure of love and an emblem for all that Goethe represented, the humane culture which - to return to Steiner - can coexist comfortably with unspeakable inhumanity. The Nazis were proud of Goethe's tree that stood in Buchenwald. The Jews, on the other hand, apostrophise the ashen-haired Shulamit from Song of Songs, the antitype of the Aryan woman, who is assigned to the crematorium, to ash. This is the fate of Celan's own German-speaking German-Jewish cultural heritage with which he grew up in Czernowitz.

The juxtaposition of the two female lovers alerts us to a larger movement of Celan's poem not to cut off or erase the poetics of the past but to audaciously answer it and to rewrite it. The poet is asking how the poetry that was the backbone of German civilisation could be read with knowledge of the death camps. The poet has not rejected Goethe and the German literary tradition in which he is writing. Rather, he is showing his dislocation in a reality of death that is far from beautiful as in European music and poetry. He is playing a counter-fugue to that of the Meister Johann Sebastian Bach, thereby undermining the aesthetics of beautiful death.

Indeed, on closer reading Celan's poem appears to be in dialogue with other Romantic and modernist poetry in German, echoing in ironic allusions that

\footnotetext{
${ }^{37}$ P. Celan: Die Gedichte..., p. 46; P. Celan: Selected Poems..., p. 31.
} 
tradition in which Celan is writing but also questioning what poetry can do when faced with the surreal reality that Celan himself experienced in Romanian forced-labour camps and in the wake of his mother's death in the Holocaust. Rooted in French and Romanian surrealism and emerging from a tradition of German-speaking poets from Bukovina, ${ }^{38}$ Celan was well-versed in Rilke and Mallarmé, Rimbaud and Verlaine, in Stefan George and Georg Trakl. Trakl was the leading avant-garde Austrian poet who ended his days watching shellshocked soldiers in a psychiatric ward committing suicide before putting an end to his own life - "Grodek" describes that surreal landscape of the First World War in which the evening sky is transformed into a universal death. In "Psalm" (second version), Trakl similarly rendered an exotic paradise as a sinister hallucination of a mental hospital inmate, writing:

Und die Schatten der Verdammten steigen zu den seufzenden Wassern nieder. In seinem Grab spielt der weiße Magier mit seinen Schlangen. ${ }^{39}$

And the shadows of the damned climb down into the sighing waters.

In his grave the white magician plays with his snakes. ${ }^{40}$

Trakl concludes, "Schweigsam über der Schädelstätte öffnen sich Gottes goldene Augen" ("Silently over Golgotha God's golden eyes open”). ${ }^{41}$ In "Todesfuge” Celan writes: "er spielt mit den Schlangen und träumet der Tod ist ein Meister aus Deutschland," as if completing Trakl's thought not with the golden eyes of a malevolent god watching over a damned world but with the Master of Death from Germany (which Felstiner leaves untranslated for the force of its sinister post-Holocaust associations of a darkening Deutschland of the Master Race). ${ }^{42}$ The "snakes" are the literal whips that the SS officer is playing with to make the Jews dig fast for the dance (in tune with the Death Tango of the original title of the poem). Celan seems to give an ambivalent answer regarding the possibility of poetry "after Auschwitz" but certainly rejects any Romantic ideal as out of touch with reality. In this he connects with other German poets who were cynical about the relevance of Hölderlin in a war-torn devastated world. ${ }^{43}$ Yet Celan

38 See T. Buck: “Kommentar.” In: P. Celan: Todesfuge. Aachen 1999, pp. 11-19.

39 G. Trakl: Dichtungen und Briefe. Eds. W. Killy, H. Szklener. Salzburg 1970, p. 32.

40 G. Trakl: Poems. Trans. J. Reidel. Calcutta 2015, p. 58 [slightly revised].

${ }^{41}$ G. Trakl: Dichtungen und Briefe..., p. 32; G. Trakl: Poems..., p. 58.

42 P. Celan: Die Gedichte..., p. 47; See J. Felstiner: Paul Celan..., pp. 36, 40. Celan would have known this use of Trakl from a poem remarkably similar to "Todesfuge" entitled "ER" by Immanuel Weissglas, a schoolmate and close friend of Celan, with whom he met regularly after liberation at the home of Rose Auslander in Czernowitz (L. Forster: "Todesfuge: Paul Celan, Immanuel Weissglas and the Psalmist." German Life and Letters 1985, vol. 39, no. 1, pp. 1-5; T. Buck: "Kommentar...," p. 22). Forster and Buck reproduce Weissglas's poem.

43 For example Günther Eich in his poem "Latrine" (published in 1946) doubted Hölderlin's faith in poetry when the snowy clouds were reflected in a pool of urine in France in 1940; there is 
was able to empathise with Hölderlin in his madness, returning to his question in "Mnemosyne" (third version) about whether the past can be put to rest when loyalty and silence are required so that the Muses can sing undisturbed.

... und ein Gesetz ist,

Daß alles hineingeht, Schlangen gleich,

Prophetisch, träumend auf

Den Hügeln des Himmels. Und vieles

Wie auf den Schultern eine

Last von Scheitern ist

$\mathrm{Zu}$ behalten. Aber bös sind

Die Pfade. Nämlich unrecht,

Wie Rosse, gehn die gefangenen

Element' und alten

Gesetze der Erd. Und immer

Ins Ungebundene gehet eine Sehnsucht. Vieles aber ist

$\mathrm{Zu}$ behalten. Und noth die Treue.

Vorwärts aber und rückwärts wollen wir

Nicht sehn. Uns wiegen lassen, wie

Auf schwankem Kahne der See. ${ }^{44}$

... and it's law,

Prophetic, that all must enter in

Like serpents, dreaming on

The mounds of heaven. And much

As on the shoulders a

Load of logs must be

Retained. But evil are

The paths, for crookedly

Like horses go the imprisoned

Elements and ancient laws

Of the earth. And always

There is a yearning that seeks the unbound. But much must

Be retained. And loyalty is needed.

Forward, however, and back we will

Not look. Be lulled and rocked as

On a swaying skiff of the sea. ${ }^{45}$

a double irony of referring to Hölderlin's "Andenken" written in southern France and the fact that Hölderlin was conscripted to the Nazi cause as a national poet. See on this R. SAVAge: Hölderlin after the Catastrophe: Heidegger, Adorno, Brecht. Rochester 2008, pp. 1-5. On Celan's response to Hölderlin's "Andenken" see R. SAVAGE: Hölderlin after the Catastrophe..., pp. 20-21; B. BöscheNSteIN: "Celan als Leser Hölderlins und Jean Pauls." In: Argumentum e Silentio..., pp. 183-198.

${ }^{44}$ F. Hölderlin: Sämtliche Werke. Vol. 2. Stuttgart 1953, p. 205.

${ }^{45}$ F. Hölderlin: Poems and Fragments. Trans. M. Hamburger. Bilingual edition. Cambridge 1980, pp. $498-499$. 
Celan could reject the way Hölderlin had been conscripted by the Nazis but he could not ignore his own inner conflicts. It is surely not insignificant that, instead of a suicide note, he left on his writing desk before drowning himself in the Seine a biography of Hölderlin open to a page with the underlined sentence: "Sometimes this genius goes dark and sinks down in the bitter well of his heart."

Celan's first mature poems date from the period 1938-1941, and a few were composed during his days in a Romanian labour camp between July 1942 and around February 1944, altogether two collections of verse, one typewritten (spring 1944), the other written out by hand, dating from fall 1944 to spring $1945 .{ }^{47}$ Celan wrote to a friend that he was writing poetry in an effort to maintain his humaneness, his Menschlichkeit, in a brutalising regime that was meant to destroy the body and the spirit. ${ }^{48}$ The poem "Winter" responds to news of his mother's death, reportedly shot in Nazi-occupied Ukraine, while "Schwarze Flocken" ("Black Flakes") was written after receiving a letter from his mother telling him of his father's death from typhus. ${ }^{49}$ Celan's biographer and translator John Felstiner comments that "Black Flakes" "holds in a single moment the European Jewish catastrophe," as well as the poet's "private loss" and his calling as a poet. When in the poem his mother asks for a shawl to keep warm in the Ukrainian winter, his poem restored "to her something at least in the mother tongue." ${ }^{50}$ If German is the poet's mother tongue, and it was clear that Celan wanted to be a poet, how can he relate to a language and culture that denied him existence? And what future was there for a Jewish poet in German? ${ }^{31}$

Felstiner calls "Todesfuge" the "benchmark of 'poetry after Auschwitz" and its reading and interpretation have been determined largely by its reception after 1952 and its anthologisation, ${ }^{52}$ to the poet's chagrin, into a conventional Holocaust poem (although it first appeared in German in Celan's debut collection Der Sand aus den Urnen in 1948). The truth is that "Todesfuge" does not witness something that Celan actually experienced himself. However unbearable the brutal conditions were in the labour camps, Jews in Romanian labour battalions were not generally sent to Auschwitz. Celan probably wrote the poem in 1944-1945 after liberation from the camps and his return to Czernowitz, which came under Soviet rule, when the few survivors were coming back from

${ }^{46}$ R. SAVAGE: Hölderlin after the Catastrophe..., p. 21.

${ }^{47}$ H. Bekker: "Remarks on the Early Poetry of Paul Celan." In: H.M. Block (ed.): The Poetry of Paul Celan: Papers from the Conference at the State University of New York at Binghamton, October 28-29, 1988. New York-Bern-Frankfurt/M.-Paris 1991, p. 6; on Celan's early poetry, see V. Liska: Die Nacht der Hymnen: Paul Celans Gedichte 1938-1944. Bern 1993.

${ }^{48}$ J. Felstiner: Paul Celan..., p. 15.

${ }^{49}$ Ibidem, pp. 15-21.

${ }^{50}$ Ibidem, p. 21.

${ }^{51}$ On the exemplary paradox of this question see V. Liska: German-Jewish Thought and Its Afterlife: A Tenuous Legacy. Bloomington 2017.

${ }^{52}$ Ibidem, p. 26. 
the death camps. It was apparently written on the basis of a Soviet propaganda pamphlet by the Russian writer Konstantin Simonov, which described the Lublin (Majdanek) concentration camp and recounted that tangos and foxtrots were played as the condemned victims were murdered. Celan's familiarity with this source can be surmised from an editorial note to the first publication of the poem, in a Romanian translation in May 1947 by Celan's friend Petre Solomon under the title "Death Tango." As Felstiner notes, the "Death Tango," presumably the popular "Tango de la Muerte," was played at the notorious Janowska Road camp near Lviv as graves were dug and people were tortured to death, but it was also a name given to whatever music was played in other camps for purposes of sadistic cruelty. However, it is not any historical or biographical authenticity that gives the poem its force of immediacy but rather its disruptive diction and rhythm that works against the obscene musicality of the death tango. ${ }^{53}$

Celan's much discussed poetics of negativity does create a new language, in German, a language, as George Steiner astutely noted, that had been sanitised and neutered by the Nazis and put to work to dispossess the Jews, process them for deportation and finally Vernichtung - annihilation, or "special treatment." 54 Celan explained that the terrible thing which had happened changed German poetry in ways that did not affect French poetry. Answering a question from a French bookstore about his work in progress in 1958, he asserted that German poetry "can no longer speak the language which many willing ears seem to expect. Its language has become more sober, more factual[,] [...] a language which wants to locate even its 'musicality' in such a way that it has nothing in common with the 'euphony' which more or less blithely continued to sound alongside the greatest horrors." 55 And he adds, "It does not transfigure or render 'poetical'; it names, it posits, it tries to measure the area of the given and the possible." 56

At the same time the dislocation of language is a dislocation of the poet, who has to retrace his steps given the contradiction we saw in "Todesfuge" between his German cultural identity and the German state's denial of his existence. In his Bremen speech, also in 1958, Celan spoke of the survival of language "secure against loss," all that was left after the disaster to help orient himself en route in his search for cultural identity, to chart his reality: "But it had to go through its own lack of answers, through terrifying silence, through the

${ }^{53}$ Ibidem, p. 30; T. Buck: "Kommentar...," pp. 26-30.

${ }^{54}$ See G. Steiner: Language and Silence..., pp. 95-107. On Celan's "poetics of negativity" see D. Feldman: "Writing Nothing: Negation and Subjectivity in the Holocaust Poetry of Paul Celan and Dan Pagis." Comparative Literature 2014, vol. 66, no. 4, pp. 438-458; W. Franke: "Poetics of Silence in the Post-Holocaust Poetry of Paul Celan." Journal of Literature and Trauma Studies 2014, vol. 2, no. 1, pp. 137-158.

${ }_{55}^{5}$ P. Celan: Collected Prose. Trans. R. Waldrop. Manchester 1986, p. 35.

${ }^{56}$ Ibidem, p. 36. 
thousand darknesses of murderous speech. It went through. It gave me no words for what was happening, but went through and could resurface, 'enriched' by it all." ${ }^{57}$ Comparing these statements to Adorno's comments on Beckett's Endgame, Eric Kligerman explains that Celan refers to the event which cannot be named: "The name of the disaster [Umheil] can only be spoken silently." ${ }^{88}$ Kligerman concludes that both Celan and Beckett "distanced themselves from symbolic representations by violating syntax and grammar in order to expose the restrictions which language faced in the midst of catastrophic history." ${ }^{59}$ In Aesthetic Theory Adorno commented on Celan's poems that they showed the shame of art before experience of suffering and "want to speak of the most extreme horror through silence. Their truth content itself becomes negative." ${ }^{\prime \prime}$

\section{Poetry as Resistance}

The modernist Yiddish poet Abraham (Avrom) Sutzkever was unexpectedly catapulted into the role of bard of the Vilna ghetto, where he was both witness and participant in cultural and spiritual resistance, though tormented by inner qualms over his preoccupation with poetry instead of fighting or wreaking vengeance. ${ }^{61}$ Sutzkever was already a well-known poet and public figure before the German invasion of Lithuania and had established a reputation in the interwar years for his experimental nature poetry, which followed the neo-Romanticism of Cyprian Norwid but did not endear him to the avant-garde Yiddish poets in Vilna. ${ }^{62}$ The poems Sutzkever wrote in the ghetto (collected in Di festung (The

${ }^{57}$ Ibidem, p. 34.

58 Adorno quoted in E. Kligerman: "Celan's Cinematic Anxiety of the Gaze in Night and Fog and 'Engführung'." In: D. Bathrick, B. Prager, M.D. Richardson (eds.): Visualizing the Holocaust: Documents, Aesthetics, Memory. Rochester 2008, p. 186.

${ }^{59}$ E. Kligerman: "Celan's Cinematic Anxiety...," p. 186.

60 T.W. Adorno: Aesthetic Theory. Eds. G. Adorno, R. Tiedemann. Trans. R. Hullot-Kentur. Minneapolis 1997, p. 322.

${ }^{61}$ D.G. Roskies: Against the Apocalypse: Responses to Catastrophe in Modern Jewish Culture. Cambridge 1984, pp. 227-257; M. KvietKausas: “Poetisches Zeugnis: Abraham Sutzkever." In: E.-V. Kотоwsкi, J.H. Schоеps (eds.): Vilne, Wilna, Wilno, Vilnius: eine jüdische Topografie zwischen Mythos und Moderne. Berlin 2017, pp. 91-101.

${ }^{62}$ H. Pollin-Galay: "Avrom Sutzkever's Art of Testimony: Witnessing with the Poet in the Wartime Soviet Union." Jewish Social Studies 2015, vol. 21, no. 2, pp. 4-5; R. Wisse: "Introduction: The Ghetto Poems of Abraham Sutzkever." In: A. Sutzkever: Burnt Pearls: Ghetto Poems of Abraham Sutzkever. Oakville 1981, pp. 1-18; J. Cammy, M. Figlerowicz: "Translating History into Art: The Influences of Cyprian Kamil Norwid in Abraham Sutzkever's Poetry." Prooftexts 2007, vol. 27, no. 3, pp. 427-473. D. KaC: Wilno Jerozolima było: Rzecz o Abrahamie Sutzkeverze. Sejny 2004, pp. 83-92. 
fortress, 1946) and Lider fun geto (Poems from the ghetto, 1947)) were composed without knowing what the next day would bring, in inhuman conditions of total physical and psychological devastation, as a recent scholar puts it: "One theme that arises throughout his diverse ghetto poetry concerns the Jewish capacity to speak, to become cognizant of one's suffering, and to convey it aloud." ${ }^{63}$ After the war his epic Geheymshtot (Secret City, 1948) was hailed as "a centerpiece to that new entity called 'Holocaust poetry."." ${ }^{4}$ His poems recording the daily death which the ghetto Jews lived through reflect his sense of responsibility until the day he fled to join the partisans in the forests, exchanging cultural or spiritual resistance for a gun, feeling that no more could be done to save those left behind after a leading resistance fighter was forced to give himself up.

The mission of the poet demanded faith in the exalted task of poetry. Sutzkever fervently believed in "the power and the wonder of poetry and of the Yiddish language." ${ }^{\prime 5}$ Sutzkever's oxymorons were the only way in which to describe the impossible and unbelievable reality in which he was trapped. ${ }^{66}$ When he was made to dig his own grave, he cut a worm in two and marveled at the worm's stubborn rebirth and insistence on living, a lesson he turned into a poem. ${ }^{67}$ Poetry restored his determination to live, but it also had the power to save his life. In March 1944 it did save him in his perilous escape from German soldiers through a minefield: he followed the rhythm of a tune in his head as he stepped through this field of death until he was safe. ${ }^{68}$

It was out of his personal anguish that Sutzkever created his aesthetics: Sutzkever lost both his mother and his newborn son, murdered by soldiers carrying out an edict that prohibited Jewish children being born. Addressing the dead child, the poet asks:

Far vos hostu fartunkelt dem bashaf, mitdem vos du host tsugemakht di oygn un gelozt mikh betlerdik in droysn tsuzamen mit velt an oisgeshnayter, vos du host opgevorfen oyf tsurik? Why have you darkened all Creation By closing your eyes

${ }^{63}$ H. Pollin-Galay: "Avrom Sutzkever's Art of Testimony...," p. 5.

${ }^{64}$ H. Pollin-Galay: "The Epic Demands of Postwar Yiddish: Avrom Sutzkever's Geheymshtot (1948)." East European Jewish Affairs 2018, vol. 48, no. 3, p. 332.

${ }^{65}$ A. Sutzkever: "My Life and My Poetry." In: A. Sutzkever: Zingt alts nokh mayn vort / Still My Word Sings: Lider / Poems. Trans. and ed. H. Valencia. Bilingual edition (Yiddish and English). Dusseldorf 2017, p. 45.

${ }^{66}$ D.G. Roskies: "Did the Shoah Engender a New Poetics?...," pp. 347-350.

${ }^{67}$ Ibidem, pp. 45-47.

${ }^{68}$ Ibidem, p. 47. 
And leaving me outside, a beggar,

Together with a snowed-up world,

Which you have cast behind you? ${ }^{69}$

Sutzkever's child is the third person in conjugal union and his absence leaves the poet incomplete, a beggar in a desolate world. But he cannot live as the boy's tomb and releases him to the snow, to nature which had filled Sutzkever's early poetry with joy and splendour but which is now frozen. Relating how he found his wife lost in the swamps by beating a stone against a tree, he declared: "When he is completely anguished and despairing, the poet grabs some word or other and begins to beat with the word and with his head and with his heart against a deaf wall, and then it happens, in a blessed moment, when he is still lying there in despair, that his poem emerges out of the wilderness..."70

Sutzkever believed that he literally owed his survival to poetry as he chronicled daily life in the ghetto as the "last poet in Europe" (der letster poet in Eyrope), as he called himself in 1943, a voice in a void awaiting extinction. ${ }^{71}$ As a member of the so-called Paper Brigade ordered to sort and destroy Vilna's libraries, he participated in smuggling precious books and manuscripts to safety under the noses of the SS, a literal rescue of the word, which he describes, in a poem "kerndelekh vaytz" ("Grains of Wheat"). These grains he buries wherever he can in order to preserve the soul of Yiddish, in the belief that, like the grain in the storehouses of the Egyptian Pharaoh, they will sprout and bloom at some future time, nourishing the survivors with these precious words. Moreover, the poet extends the analogy of the word and the soul of the people in the (imagined) story of how members of the Jewish ghetto resistance broke in to the Romm press, famous for its editions of the Talmud, in order to use the lead type as bullets. In this invented legend, they literally forged a chain in Jewish cultural and national history by turning words into weapons, precisely when a new vocabulary had to be invented for the unprecedented destruction of both Jewish life and word that could only be resisted if words were melted down into bullets:

dos blay hot geloykhtn baym oysgisn koyln makhshovos-tsegangen an oys nokh an oys a shuroh fun bovel, a shuroh fun poylin. gezoten, geflaytst in der zelbiker mos. di yidishe gevuroh in verter farhoyln, muz oyfraysn itster di velt mit a shos!

${ }^{69}$ A. Sutzkever: “Tsum kind” / “To My Child.” In: A. Sutzkever: Still My Word Sings..., pp. 96-97.

70 A. Sutzkever: "My Life and My Poetry...," p. 53.

${ }^{71}$ D.G. Roskies: "Did the Shoah Engender a New Poetics?...," p. 347. 
The lead shone as from it we poured the bullets, Thoughts melted together-letter by letter.

One line from Babylon, one line from Poland

Seethed, flooded into identical moulds.

And now Jewish valour, concealed in these words

Must with a gunshot tear open the word! $!^{2}$

The fire that consumed the word, the burning of Jewish culture, enrages the poet, but what moves him most is the sight of the dying pyre, where the "froy in flam gevasht" ("woman washed in flames") is unrecognisable in the "gro-farbrente perl in di ashn" ("grey burnt pearls in the ashes"). ${ }^{73}$ The oxymoronic "washed in flames" suggests a baptism of fire, while the burnt pearls are all that are left of the poet's love, his Yiddish culture, and the words with which to create poetry.

Yet not only did individual experiences differ during the Holocaust, but situations varied from one location to another: the cultural resistance of Sutzkever and Abba Kovner in the Vilna ghetto followed the slaughter of sixty thousand Vilna Jews, while in Warsaw between deportations the Oneg shabos archive was recording everyday life. After the liquidation of the Warsaw Ghetto, Yitzkhak Katselnelson wrote his Song of the Murdered Jewish People, whose diction and language contrast with the undermining of conventional metaphor and imagery in Celan and Sutzkever. Like Sutzkever, the Polish poet Czesław Miłosz voiced resistance in the abyss and watched the destruction of the Warsaw ghetto with a disturbingly fascinated gaze. His language, like Sutzkever's, is terse and disturbing in its distanced yet unflinching documentation of immediate horror. Both poets were modernists in their description of nature. However, Miłosz wrote as a bystander, not as a victim slated for extinction, yet he too was aware that his poetry was all he had to resist complicity with evil.

\section{Excavating a Language of Humanity}

It is not poetry that rings false but a Romantic vision of humanity and nature, of innocence and tranquility as natural states. Miłosz exposes the true state of affairs in a language that touches the raw nerve of writing poetry during the Holocaust. He writes in "Biedny chrześcijanin patrzy na getto" ("A Poor Christian Looks at the Ghetto," 1943):

${ }^{72}$ A. Sutzkever: "Di blayene platn fun roms drukeray" / "The Lead Plates of Romm's Printing House." Vilna ghetto, September 12, 1943. In: A. Sutzkever: Still My Word Sings..., pp. 106-107.

${ }^{73}$ A. Sutzkever: "Farbrente perl” / "Burnt Pearls." In: A. Sutzkever: Still My Word Sings..., pp. 104-105. 
Pszczoty obudowują czerwona wątrobę

Mrówki obudowują czarna kość

Rozpoczyna się rozdzieranie, deptanie jedwabi,

Rozpoczyna się tłuczenie szkła, drzewa, miedzi, niklu, srebra, pian

Gipsowych, blach, strun, trąbek, liści, kul, kryształów -

Pyk! Fosforyczny ogień z żółtych ścian

Pochłania ludzkie i zwierzęce włosie. ${ }^{74}$

Bees build around red liver,

Ants build around black bone.

It has begun: the tearing, the trampling on silks,

It has begun: the breaking of glass, wood, copper, nickel, silver, foam

Of gypsum, iron sheets, violin strings, trumpets, leaves, balls, crystals.

Poof! Phosphorescent fire from yellow walls

Engulfs animal and human hair. ${ }^{75}$

This poem was written to witness the Warsaw Ghetto Uprising in April 1943 by a "Jew of the New Testament" who is aware he may be numbered among the accomplices of death. Miłosz attempts to find a language of complete dehumanisation, of utter destruction, to create a poetry that can imagine nature without human beings, where the human body has been erased and where the organs of the corpses are waste material for building, a construction that is also a destruction, their belongings sorted into materials for salvage.

The mysterious "guardian mole" tunneling through the corpses, however, can recognise the human by the tell-tale "luminous vapor" that distinguishes the ashes of each individual. It is this underground mole, a miner of souls but also a spy and a bearer of conscience, who rescues the human from the decomposition effected by the language of the poem itself. The poet is therefore rightly afraid that the patriarchal mole, who has been reading the "great book of the species" (presumably the Bible), might in his moral accounting find him guilty as one of the helpers of death, one of the uncircumcised waiting two thousand years for the Christian messiah, who has betrayed the universal ethics of his faith. The identification of the poet as a "poor Christian," not with the victims but with the complicity of bystanders, is a silent indictment not so much of the failure of Poles to feel compassion for their murdered Jewish neighbours but of the failure of the poet himself to do anything to save or redeem the victims.

In "Campo di Fiori" (1943) Miłosz watches the carefree crowds on the merrygo-round as the ghetto burns and challenges the poetics of the heroic, of the beautiful, of the humane. The poet draws a parallel with the carnival atmosphere at the burning of the 16th-century heretic Giordano Bruno:

${ }^{74}$ C. MiŁosz: Poezje. Vol. 1. Paris 1981-1982, p. 107.

75 C. MıŁosz: “A Poor Christian Looks at the Ghetto." In: C. Mıєosz: The Collected Poems, 1931-1987. Trans. the author with R. HAss and others. London 1988, p. 64. 
Czasem wiatr z domów płonących

Przynosił czarne latawce,

Łapali płatki w powietrzu

Jadący na karuzeli.

Rozwiewał suknie dziewczynom

Ten wiatr od domów płonących,

Śmiały się tłumy wesołe

W czas pięknej warszawskiej niedzieli. ${ }^{76}$

At times wind from the burning

would drift dark kites along

and riders on the carousel

caught petals in midair.

This same hot wind

blew open the skirts of the girls,

and the crowds were laughing

on a beautiful Warsaw Sunday. ${ }^{77}$

The poet is aware that the merry-makers are not touched by the ashes blowing in their faces from the burning houses of the Jews, but the extinction of the Jews' "strange tongue" must affect his tongue if he is to remain a Christian. He must speak the ancient language of martyrdom (not necessarily the language of the Jews) in order to restore the language of poetry itself. The crowd is quite indifferent to the destruction of the ghetto; in fact, the charred "petals" and the wind blowing from the fire destroying the ghetto only add to the fun of a fairground on a beautiful Warsaw Sunday in spring.

This poetic testimony goes beyond horror to an indictment of moral complicity that makes a statement about the vanity of human lives. Jan Błoński later suggested Miłosz was addressing Polish denial of their moral duty in not facing the truth of what happened in Poland under German occupation. ${ }^{78}$ Yet, the poet concludes that this is not the point. Both the martyrdom of Giordano Bruno and that of Warsaw's Jews are calls for the poet to find the "language of an ancient planet" ("język dawnej planety"), so that one day after many years have passed rage will kindle at a poet's word: "Na nowym Campo di Fiori / Bunt wznieci słowo poety." That conclusion supports Błoński’s reading of the poem "Przedmowa" ("Dedication," 1945) as a call for a combative poetry: the poet asks "Czym jest poezja, która nie ocala / Narodów ani ludzi?" ("What is poetry which does not save / Nations or people?"), but the poet answers this rhetorical question with

76 C. MiŁosz: Poezje..., pp. 90-91.

77 C. MıŁosz: The Collected Poems..., pp. 33-34 [slightly revised].

78 J. BŁoński: "Biedni Polacy patrzą na getto." Tygodnik Powszechny, 11.01.1987. Translated as "Poor Poles Look at the Ghetto." Yad Vashem Studies 1988, vol. 19, pp. 357-367.

79 C. MiŁosz: Poezje..., p. 35. 
a resignation to official lies and drunkards' singing. Salvation, the poet is saying, can be found only in the recognition of the higher aims of good poetry. ${ }^{80}$ The poet could not save his friend, but he places his book of poems figuratively on his grave to placate the ghosts of the dead. ${ }^{81}$ This was written after the crushing of the Warsaw Uprising in 1944 and the subjugation of Poland to the Kremlin. In the ruins of Warsaw and after the complete destruction of the Jews, Miłosz does not believe in poetry driven by ideology. The 20th century has demonstrated the fragility of civilisation and culture: "What surrounds us, here and now, is not guaranteed. It could just as well not exist-and so man constructs poetry out of the remnants found in ruins." 82

In the Marxist critic Terry Eagleton's reassessment of Adorno's Negative Dialectics, Auschwitz did not invalidate the aesthetic project, even if its terms of reference were permanently tainted by fascism and mass culture, but it did change the aesthetics of pleasure. The body signified suffering, not pleasure: the body was condemned to a living death beyond endurance. A global history of humanity would now stretch from the slingshot to the atom bomb as one story of scarcity and oppression, a fable of permanent catastrophe. ${ }^{83}$ This skeletal post-Nietzschean vision, familiar from Samuel Beckett's existential landscapes, attempts to recover in the erasure of the body that we saw in Miłosz a site for the aesthetic.

\section{It Is Always After}

Is any of this new? Have not prophets and poets down the ages subverted poetic metaphor in order to force us into an awareness of extremity, atrocity, of the ineffable and the unspeakable? Modernity in particular revealed a violence that was unprecedented in human experience. Paul Fussell in his seminal book on the writing of the First World War remarks how literature and real life intersect. It is as if the figural has become literal and the familiar literal use of language can only be read figuratively. Fussell noted that Siegfried Sassoon wrote in retrospect that the terrible irony of Thomas Hardy's prewar poetry gave him the sardonic satirical voice for his own vision of death and despair. ${ }^{84}$ As Henry James understood on the outbreak of the First World War in 1914, the descent into bloodshed and death reversed the myth of the Age of Progress. Indeed,

\footnotetext{
80 Ibidem, p. 124; C. MıŁosz: Collected Poems..., p. 78.

81 Ibidem, p. 79.

82 C. MiŁosz: The Witness of Poetry. Cambridge 1983, p. 97.

83 T. Eagleton: Ideology of the Aesthetic. Oxford 1990, pp. 242-262.

84 P. Fussell: The Great War and Modern Memory. Oxford 1975, p. 7.
} 
historiographical attempts to impose some continuity and order could not hide the lack of any rationality in the conduct of the war, which apart from two major battles, if that is what they can be called, was characterised by the stalemate of trench warfare, of suicidal attempts to decide the conflict, which remained largely unchanged for over four years of stalemate, interrupted by unsuccessful assaults by each side which cost thousands of casualties among the infantry. ${ }^{85}$ Siegfried Sassoon's reading of Hardy's Tess of the D'Urbervilles in the trenches is just one of Fussell's examples of the intersection of literature and life as the war took on fantastic and surreal aspects, exacerbated by the assumptions behind the class system which alienated a conscript army. Poet laureate Robert Bridges's anthology of poetry The Spirit of Man (1915), which sought to bolster morale, looked to spirituality in order to address an unprecedented horror on the front. ${ }^{86}$ Yet the loss of innocence that marked the experience of trench warfare allowed few hints of redemption in a relentless and ceaseless war of attrition, ${ }^{87}$ in which millions were maimed and mutilated in vain (sacrifice was one of the common tropes of patriotic devotion to King and country). Wilfred Owen's response to Rupert Brooke's "The Soldier" was constrained by the diction of Georgian convention in "Dulce et Decorum Pro Patria Mori" but undermined the aesthetics of patriotic poetry. Indeed, his description of preparing the Christ-soldier for his daily crucifixion allows little idea of redemption..$^{88}$ Literature did sustain men on the front (as in ironical or literal readings of Pilgrim's Progress) and did produce literature, but it was a literature that contradicted the ideology behind existing poetic forms. Fussell assesses attempts to describe modern trench warfare "factually" as failures because conventional rhetoric and clichés were inadequate to communicate to those who were not there the full horror of the experience. It is not that there was no language, but it required an idiom and style appropriate for what was indescribable, an unending sequence of events that had no meaning and defeated attempts to admit causality. ${ }^{89}$

Nevertheless, we do not get a sense of the crack in Western epistemology or a challenge to established cosmology until we come to Wilfred Owen's "Futility" with its anti-theology of hopeless despair. Thinking how even the sun can warm the seeds in the ground to life but cannot rouse a fallen soldier, a body full of strength, he asks:

Was it for this the clay grew tall?

- O what made fatuous sunbeams toil

To break earth's sleep at all? ${ }^{90}$

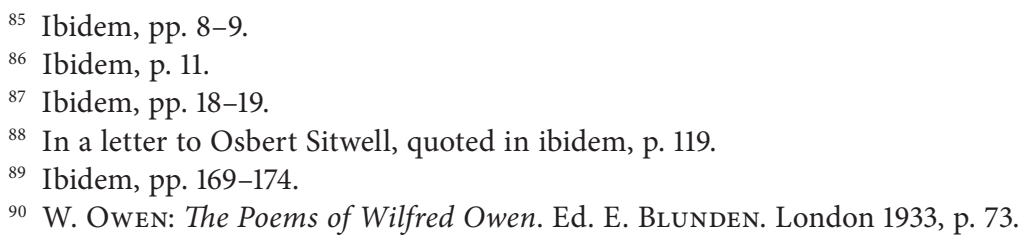


Celan faces an even emptier universe, apparently devoid of a creator of Owen's primeval clay, and addresses his "Psalm" paradoxically to "Niemand" ("Nobody"):

Niemand knetet uns wieder aus Erde und Lehm, niemand bespricht unseren Staub.

Niemand.

Gelobt seist du, Niemand.

Dir zulieb wollen

wir blühn.

Dir

entgegen. ${ }^{91}$

No one kneads us again out of earth and clay, no one incants our dust.

No one.

Blessèd art thou, No One.

In thy sight would

we bloom.

In thy

spite. ${ }^{92}$

Yet Trakl too concludes his depiction of damnation and death in a silent malignant universe in the second version of his "Psalm." For his part, Sutzkever is not religious (though tutored in Jewish tradition), yet he feels the need to pray to an absent deity in the ghetto but his prayer is no less heartfelt because it is beyond despair in an empty universe where the poet has lost his speech, his words:

efshar zol ikh betn bay a shtern. 'fraynd mayn vayter, kh'hob mayn vort farloyrn, kum un zay im a farbayter'! oykh der guter shtern vet es nit derhern.

Perhaps I'll pray to a star: 'Hear, my distant friend, I have lost my word; oh, come and take its place!'

But even the good star

will not hear my prayer. ${ }^{93}$

${ }^{91}$ P. Celan: Die Gedichte..., p. 136.

92 P. Celan: Selected Poems and Prose..., p. 157. On Celan's negative theology in this poem see A. Lipszyc: "The Stylus and the Almond: Negative Literary Theologies in Paul Celan." In: M. Fagenblat (ed.): Negative Theology as Jewish Modernity. Bloomington 2017, pp. 304-321.

${ }^{93}$ A. Sutzkever: "Glust zikh mir tsu ton a tefiloh" / "I Long to Say a Prayer." Vilna ghetto, January 17, 1942. In: A. Sutzkever: Still My Word Sings..., pp. 94, 95. 
The poet feels impelled to "make a prayer" ("ton a tefiloh"), rather than the traditional davenen, yet without an addressee the poet is left to babble until daybreak in an apparently empty universe. To write amid annihilation is to hold on to the possibility of an addressee, not the God of Israel who has apparently abandoned or betrayed His people, but an audience, a surviving readership who will redeem those senseless words into meaning. ${ }^{94}$

Scholars who maintain that Holocaust poetry marks a break from anything written before sometimes ignore the prehistory of these poets and their literary context, as well as the wider corpus of their work (for example the cycles in which these poems by Celan or Miłosz were published, rather than their appearance in anthologies of Holocaust literature). The First World War poets sought a language to express the unspeakable violence of modernity in order to protest the stupidity of war so that it might not happen again, and Joseph Conrad gave a glimpse into knowledge of inhuman horror in the heart of Europe's own darkness. However, Holocaust poets were writing when there was no hope for humanity or themselves and they continued to both breathe and write in order to preserve a trace of their existence and tell the world what they had gone through, to find words that would witness the unbelievable, something which only they knew and understood. If there was ever a delusion of a stable universe with shared assumptions of universal values, there was now a before and an after that drew the line between the familiar and safe prewar world and the real, unspeakable present. Close scrutiny of the poetry of Celan, Sutzkever, and Miłosz reveals just how much they owe to their poetic heritage and yet how radical was their revision of that heritage in their responses to catastrophe. When everything has changed and all values have been destroyed, the concept and practice of poetry can no longer remain the same.

\section{Bibliography}

Aaron F.W.: Bearing the Unbearable: Yiddish and Polish Poetry in the Ghettos and Concentration Camps. Albany 1990.

Adorno T.W.: Aesthetic Theory. Eds. G. Adorno, R. Tiedemann. Trans. R. Hullot-

Kentur. Minneapolis 1997.

Adorno T.W.: Gesammelte Schriften. Frankfurt/M. 1951.

Adorno T.W.: Negative Dialectics. Trans. E.B. Ashton. New York 1973.

Adorno T.W.: Notes to Literature. Trans. S.W. Nicholsen. New York 1992.

Adorno T.W.: Prisms. Trans. S.M. Weber, S. Weber. Cambridge 1981.

Alexander E.: "Patterns of Holocaust Poetry: Representative Voices in Yiddish and

Hebrew.” In: A.D. Colin (ed.): Argumentum e silentio: International Paul Celan Symposium. Berlin 1987, pp. 296-319.

\footnotetext{
${ }^{94}$ See D.G. Roskies: Against the Apocalypse..., pp. 237-238.
} 
Antelme R.: "Poetry and the Testimony of the Camps." In: D. Dobbels (ed.): On Robert Antelme's The Human Race: Essays and Commentary. Evanston 2003, pp. 31-34. First published in Le patriote resistant 1948, vol. 53.

Bekker H.: "Remarks on the Early Poetry of Paul Celan." In: H.M. Block (ed.): The Poetry of Paul Celan: Papers from the Conference at the State University of New York at Binghamton, October 28-29, 1988. New York-Bern-Frankfurt/M.-Paris 1991, pp. 6-12.

Benjamin W.: Illuminationen: ausgewählte Schriften. Frankfurt/M. 1977.

Benjamin W.: Illuminations. Ed. H. Arendt. Trans. H. Zohn. New York 1968.

BŁoński J.: "Biedni Polacy patrzą na getto.” Tygodnik Powszechny, 11.01.1987. Translated as "Poor Poles Look at the Ghetto." Yad Vashem Studies 1988, vol. 19, pp. 357-367.

Böschenstein B.: "Celan als Leser Hölderlins und Jean Pauls." In: A.D. Colin (ed.): Argumentum e Silentio: International Paul Celan Symposium. Berlin 1987, pp. 183-198.

Buck T.: “Kommentar.” In: P. Celan: Todesfuge. Aachen 1999, pp. 9-51.

Cammy J., Figlerowicz M.: "Translating History into Art: The Influences of Cyprian Kamil Norwid in Abraham Sutzkever's Poetry.” Prooftexts 2007, vol. 27, no. 3, pp. 427-473.

Celan P.: Collected Prose. Trans. R. Waldrop. Manchester 1986.

Celan P.: Die Gedichte. Ed. B. Wiedemann. Berlin 2018.

Celan P.: Gesammelte Werke. Ed. B. Allemann, K. Reichert. Vol. 3. Frankfurt/M. 1983.

Celan P.: Selected Poems and Prose. Trans. J. Felstiner. Bilingual edition. New York 2001.

Celan P.: Todesfuge. Aachen 1999.

Colin A.D. (ed.): Argumentum e Silentio: International Paul Celan Symposium. Berlin 1987.

Eagleton T.: The Ideology of the Aesthetic. Oxford 1990.

Ezrahi S.D.: By Words Alone: The Holocaust in Literature. Chicago 1980.

Feldman D.: "Writing Nothing: Negation and Subjectivity in the Holocaust Poetry of Paul Celan and Dan Pagis." Comparative Literature 2014, vol. 66, no. 4, pp. 438-458.

Felman S.: "Education and Crisis, or the Vicissitudes of Teaching." In: S. Felman, D. Laub: Testimony: Crises of Witnessing in Literature, Psychoanalysis, and History. New York 1992, pp. 1-56.

Felman S., Laub D.: Testimony: Crises of Witnessing in Literature, Psychoanalysis, and History. New York 1992.

Felstiner J.: Paul Celan: Poet, Survivor, Jew. New Haven 1995.

Forché C. (ed.): Against Forgetting: Twentieth-Century Poetry of Witness. New York 1993.

Forché C., Wu D. (eds.): The Poetry of Witness: The English Tradition, 1500-2001. New York 2014.

Forster L.: “'Todesfuge’: Paul Celan, Immanuel Weissglas and the Psalmist.” German Life and Letters 1985, vol. 39, no. 1, pp. 1-20.

Franke W.: "Poetics of Silence in the Post-Holocaust Poetry of Paul Celan." Journal of Literature and Trauma Studies 2014, vol. 2, no. 1, pp. 137-158.

Fussell P.: The Great War and Modern Memory. Oxford 1975. 
Fynsk C.: "Poetic Relation: Celan's Bremen Address." In: H.M. Block (ed.): The Poetry of Paul Celan: Papers from the Conference at the State University of New York at Binghamton, October 28-29, 1988. New York-Bern-Frankfurt/M.-Paris 1991, pp. 22-29.

Gubar S.: Poetry after Auschwitz: Remembering What One Never Knew. Bloomington 2003.

Gubar S.: “The Long and Short of Holocaust Verse.” New Literary History 2004, vol. 35, no. 3, pp. 443-469.

Hölderlin F.: Poems and Fragments. Trans. M. Hamburger. Bilingual edition. Cambridge 1980 .

HöLdERLin F.: Sämtliche Werke. 6 vols. Stuttgart 1953.

Hoyer J.M.: "Flowerless Gardeners: Poetry after Auschwitz." In: D. Stuber (ed.): Holocaust Literature. Ipswich 2016, pp. 182-199.

KAC D.: Wilno Jerozolima było: Rzecz o Abrahamie Sutzkeverze. Sejny 2004.

Kligerman E.: "Celan's Cinematic Anxiety of the Gaze in Night and Fog and 'Engführung."” In: D. Bathrick, B. Prager, M.D. Richardson (eds.): Visualizing the Holocaust: Documents, Aesthetics, Memory. Rochester 2008, pp. 185-210.

Kvietkauskas M.: "Poetisches Zeugnis: Abraham Sutzkever." In: Vilne, Wilna, Wilno, Vilnius: eine jüdische Topografie zwischen Mythos und Moderne. Eds. E.-V. KoTOWsкi, J.H. SCHOEPs. Berlin 2017, pp. 91-101.

LANGer L.: The Holocaust and the Literary Imagination. New Haven 1975.

Liska V.: Die Nacht der Hymnen: Paul Celans Gedichte 1938-1944. Bern 1993.

Liska V.: German-Jewish Thought and Its Afterlife: A Tenuous Legacy. Bloomington 2017.

Lyotard J.-F.: Heidegger and “the Jews." Trans. A. Michel, M.S. Roberts. Minneapolis 1990.

Lipszyc A.: "The Stylus and the Almond: Negative Literary Theologies in Paul Celan." In: M. Fagenblat (ed.): Negative Theology as Jewish Modernity. Bloomington 2017, pp. 304-321.

MiŁosz C.: Poezje. 3 vols. Paris 1981-1982.

MiŁosz C.: The Collected Poems, 1931-1987. Trans. the author with R. HAss and others. London 1988.

MiŁosz C.: The Witness of Poetry. Cambridge 1983.

Owen W.: The Poems of Wilfred Owen. Ed. E. Blunden. London 1933.

Pollin-Galay H.: “Avrom Sutzkever's Art of Testimony: Witnessing with the Poet in the Wartime Soviet Union.” Jewish Social Studies 2015, vol. 21, no. 2, pp. 1-34.

Pollin-Galay H.: "The Epic Demands of Postwar Yiddish: Avrom Sutzkever's Geheymshtot (1948)." East European Jewish Affairs 2018, vol. 48, no. 3, pp. 331-353.

Rosenfeld A.: A Double Dying: Reflections on Holocaust Literature. Bloomington 1980.

Roskies D.G.: Against the Apocalypse: Responses to Catastrophe in Modern Jewish Culture. Cambridge 1984.

Roskies D.G.: "Did the Shoah Engender a New Poetics?" In: K. Smola (ed.): Eastern European Jewish Literature of the 20th and 21st Centuries: Identity and Poetics. Munich-Berlin 2013, pp. 347-363.

Roskies D.G. (ed.): The Literature of Destruction: Jewish Responses to Catastrophe. Philadelphia 1989. 
Roskies D.G. (ed.): Voices from the Ghetto. New Haven 2019.

Rothberg M.: "After Adorno: Culture in the Wake of Catastrophe." New German Critique 1997, no. 72, pp. 45-81.

Rowland A., Eaglestone R. (eds.): "Holocaust Poetry special issue.” Critical Survey 2008, vol. 20, no. 2.

Rowland A.: Holocaust Poetry. Edinburgh 2005.

Rowland A.: Poetry as Testimony: Witness and Memory in Twentieth-Century Poems. New York-London 2014.

SARTRE J.-P.: What Is Literature? New York 1949.

Savage R.: Hölderlin after the Catastrophe: Heidegger, Adorno, Brecht. Rochester 2008.

Schiff H. (ed.): Holocaust Poetry. London 1995.

Schmidt D.J.: "Between Meridians and Other Lines: Heidegger and Celan." In: H.M. Block (ed.): The Poetry of Paul Celan: Papers from the Conference at the State University of New York at Binghamton, October 28-29, 1988. New York-BernFrankfurt/M.-Paris 1991, pp. 30-37.

Shapiro S.E.: "Failing Speech: Post-Holocaust Writing and the Discourse of Postmodernism.” Semeia 1987, vol. 40, pp. 65-91.

Steiner G.: Language and Silence: Essays on Language, Literature, and the Inhuman. New York 1967.

Striar M.M. (ed.): Beyond Lament: Poets of the World Bearing Witness to the Holocaust. Evanston 1998.

Sutzkever A.: "My Life and My Poetry." In: A. Sutzkever: Zingt alts nokh mayn vort / Still My Word Sings: Lider / Poems. Trans. and ed. H. Valencia. Bilingual edition (Yiddish and English). Dusseldorf 2017, pp. 18-53.

Sutzkever A.: Zingt alts nokh mayn vort / Still My Word Sings: Lider / Poems. Trans. and ed. H. Valencia. Bilingual edition (Yiddish and English). Dusseldorf 2017.

Teichman M., Leder S. (eds.): Truth and Lamentation: Stories and Poems on the Holocaust. Urbana 1994.

Tettlebaum M.: “Nothing is meant quite literally': Adorno and the Barbarism of Poetry after Auschwitz." In: D. STuber (ed.): Holocaust Literature. Ipswich 2016, pp. 200-213.

Trakl G.: Dichtungen und Briefe. Eds. W. Killy, H. Szklener. Salzburg 1970.

Trakl G.: Poems. Trans. J. ReIdel. Calcutta 2015.

VICE S.: "Holocaust Poetry and Testimony." Critical Survey 2008, vol. 20, no. 2, pp. 7-17. Wiesel E.: "The Holocaust as Literary Inspiration." In: E. Wiesel, L. Dawidowicz, D. Rabinowitz, R.M. Brown (eds.): Dimensions of the Holocaust. 2nd ed. Evanston 1990, pp. 5-23.

Wisse R.: "Introduction: The Ghetto Poems of Abraham Sutzkever." In: A. Sutzkever: Burnt Pearls: Ghetto Poems of Abraham Sutzkever. Oakville 1981, pp. 1-18.

Zilcosky J.: "Poetry after Auschwitz? Celan and Adorno Revisited." Deutsche Vierteljahrsschrift für Literaturwissenschaft und Geistesgeschichte 2005, vol. 79, no. 4, pp. 670-691. 
Efraim Sicher

\section{Poetyka Holokaustu? Na przykładzie trzech poetów}

Aвstrakt: Niezależnie od tego, czy postrzegamy Holokaust jako wydarzenie jedyne w swoim rodzaju, czy też jako kulminację serii katastrof w historii Żydów, bez wątpienia pisarstwo będące wynikiem Holocaustu warte jest badania jako zarówno świadectwo, jak i dzieło literackie. W niniejszym artykule przyglądam się poezji czasów Holokaustu, tym razem bez odniesienia do często cytowanego i przekręcanego dictum Adorna na temat poezji po Auschwitz. Mój esej kwestionuje binarną opozycję, którą można sprowadzić do przeciwstawnych stwierdzeń: „poezja Holokaustu jest barbarzyństwem i niemożliwością” i „sztuka podnosi na duchu, a Holokaust tego nie zmienia". Analizuję trzy indywidualne przykłady poezji czasów Holokaustu wykorzystywanej zarówno jako środek przetrwania, jak i dania świadectwa w czasach Zagłady - nie są to przykłady twórczości retrospektywnej lub uprawianej przez poetów niebędących świadkami wydarzeń. Problemy estetyczne i etyczne były częścią pisarstwa in extremis świadomego tych wyzwań na długo przed Adornem i teorią krytyczną. W zestawieniu Celana, Suckewera i Miłosza dostrzec można desperacką próbę tych poetów, by tworzyć poezję mierzącą się z wyzwaniem momentu historycznego, mimo wszystkich dzielących ich różnic dotyczących kultur pochodzenia, tradycji językowych i literackich. Choć badacze i krytycy odczytują twórczość wymienionych poetów osobno, według mnie powinno się ich studiować jako przykład zmagania się z bezprecedensową grozą, której pełnego wymiaru historycznego i ogromu następstw wymienieni autorzy nie mogli wówczas pojąć. Nie powinniśmy już dłużej ignorować źródeł i poprzedników, z których czerpali, gdy staramy się ocenić ich dokonania w kwestii stworzenia „poetyki Holokaustu” zdolnej wyrazić nieadekwatność języka i niewystarczalność wyobraźni w próbie oddania niewypowiadalnego, którego poeci doświadczyli osobiście w swojej codzienności. Jeśli będziemy czytać inaczej niż „po Adornie”, może to zaowocować bardziej zniuansowaną dyskusją o tym, czy istnieje poetyka Holokaustu.

SŁowA KluCze: Holokaust, poezja, trauma, poetyka, Abraham Suckewer, Paul Celan, Czesław Miłosz

EFRAIM SiCHER - profesor literatury porównawczej i angielskiej na Uniwersytecie Ben Guriona w Beer Szewie (Izrael). Autor licznych publikacji akademickich z zakresu komparatystyki literackiej i nowożytnej kultury żydowskiej. Jego główne zainteresowania badawcze obejmują kulturowy obraz Żydów, wspomnienia z okresu Holokaustu i narracje "drugiego pokolenia” - potomków Ocalałych. Efraim Sicher opublikował m.in. Breaking Crystal: Writing after Auschwitz (redakcja, 1998); Holocaust Novelists: Dictionary of Literary Biography, volume 99 (redakcja, 2004); The Holocaust Novel (2005); Babel in Context (2012); Under Postcolonial Eyes: Figuring the 'jew' in Contemporary British Writing (wspólnie z Lindą Weinhouse, 2013); Race Color Identity: Discourses about the 'Jews' in the Early Twenty-First Century (redakcja, 2013); a także The Jew's Daughter: The Cultural History of a Conversion Narrative (2017). W swojej najnowszej książce, Postmodern Love: Renegotiating Identities and Spaces in Contemporary Jewish Writing, podjął temat współczesnej prozy żydowskiej. Jego najnowszy projekt badawczy skoncentrowany jest na poezji Zagłady 
Efraim Sicher, is a professor of comparative and English literature at Ben-Gurion University of the Negev. He has published widely in the fields of comparative literature and modern Jewish culture. His main research interests include the image of the Jew, Holocaust memory and narratives of the second generation. His books include (as editor) Breaking Crystal: Writing after Auschwitz (1998); (as editor) Holocaust Novelists: Dictionary of Literary Biography, volume 99 (2004); The Holocaust Novel (2005); Babel in Context (2012); Under Postcolonial Eyes: Figuring the 'jew' in Contemporary British Writing (with Linda Weinhouse, 2013); (as editor) Race Color Identity: Discourses about the 'Jews' in the Early Twenty-First Century (2013); and The Jew's Daughter: The Cultural History of a Conversion Narrative (2017). He has completed a book on contemporary Jewish fiction, Postmodern Love: Renegotiating Identities and Spaces in Contemporary Jewish Writing. His current research project focuses on the poetics of Holocaust poetry. 